\title{
The Impact of Foreign Indirect Investment in the Primary Market, Evidence on Amman Stock Exchange
}

\author{
SAMEH ABU SHANAB \\ Assistant Professor, Finance Department, Faculty of Business, Amman Arab University \\ Email: $\underline{\text { sameh_abushanab@yahoo.com }}$
}

\begin{abstract}
This research aimed at showing the independent variables was measured, i.e., the net foreign indirect investment, National deposits in Jordanian banks, Government general debt, Gross Domestic product, Money supply (M2) on the new issues of the companies listed on the Amman Stock Exchange during the period covered by the research (2005-2016). This analysis is necessary to know the overall effect of all the independent variables on the dependent variable. The second stage consisted of testing the four hypotheses of the research using simple regression analysis. The financial data were collected through the official website of the Amman Stock Exchange and the reports issued by the Central Bank of Jordan. The study found that there was a significant statistical effect at (0.10) for all the independent study variables: net foreign direct investment, internal government debt, GDP and money supply (M2) on the new issues in the primary markets. The importance of this study is the first of its kind according to the researcher's knowledge, which focused on the impact of macroeconomic variables on new issues in the primary market on the Amman Stock Exchange. The results of this study are very important for the decision-makers in the Jordanian state to highlight the importance of each variable of the study on the expansion of existing projects, or investment in new projects because of these projects of importance in increasing economic growth and employment of economic resources stalled.
\end{abstract}

Keywords: FDI, Primary, Market, Amman, Stock Exchange.

\section{Introduction}

Financial market has very vital role by providing the financial resources needed for the long term and sustainable development of different sectors of the economy. Financial Market include Capital market and Money market. Money market trade with highly marketable short-term debt instruments whereas the capital market trade with long-term securities. The capital market consider a barometer of economic and provides an effective mechanism for capital formation. The capital market is defined as an organized mechanism for effective and efficient transfer of money-capital or financial resources from the investing parties i.e. individual or institutional savers to the entrepreneurs engaged in industry or commerce in the business either in the private or public sectors of an economy.capital market divided into Primary market and Secondary market. Secondary market is the market in which used stocks are traded after they have been issued by corporations. Primary market the market in which the firms issue new securities to raise corporate capital. (Weston,996).

Primary market is principal function in raising financial capital to support new investments. primary market transactions when you purchase shares of stock just issued by company or borrow a money. in contrast the secondary market deals with previously issued, its chief function is to provide liquidity to security investors, that provides an avenue for converting financial asset into. The volume of trading in the 
secondary market is far longer than trading in the primary market, however secondary market does not support new investment (rose 2003).

Primary market facilitate securities to the investors and assist the corporate sector in arranging funds in the form of public issue, offer for sale, private placement and right issue. Public issue can be further classified into Initial Public Offer (IPO) and Further Public Offer (FPO). An Initial Public Offering (IPO) is a companys first offering of equity to the public. IPO is a major source of capital for firms. Thus IPOs market being an important part of the primary market is an important segment of capital market of the financial system, which plays a significant role in the economic growth and development of a country by transferring resources from surplus units to deficit units in an efficient and productive manner. (anudadha 2015).

A Company may raise the capital in primary market by various ways like initial public offer, right issue and private placement. An initial public offer is the selling of securities to public in the primary market. IPO give a chance to public buy a share to the Company at bid price based. There is a big difference create in IPO because companies decided the price for share on which investor are willing to buy shares and gain through a share. Company knows about the real value of their share and listing in a stock exchange. (Mayur \& Kumar, 2006).

Foreign indirect investmentFII consist financial papers held by foreign investors, FII does not give the investor the right with direct ownership of financial assets, or direct management the corporate.( onyeisi 2016).

Foreign investors buy securities for the short time of periods, This is beneficial for investors to take advantage of suitable interest rate. The objective of this kind of investment is to obtain the high rate of return .foreign investors can achieve this task with the help of passive holding of shares and trading of securities in the capital market.( Khakan 2016).

The decisions of the foreign investors to invest in the foreign countries depend on, Mainly, economic growth, the political and social stability of the country. (Haider 2016). This paper attempted to study the impact of foreign indirect investment on new issues in the primary market because the primary market, according to the researcher's opinion, shows the extent of the increase in new investments through the establishment of new projects or the expansion of existing projects, which lead to creating new jobs in the economy. Thus increasing the demand for consumption and thus increasing the employment of production resources and creating job opportunities for job seekers.

The increase in primary market issues indicates the extent of economic development in developing countries and hence the economic growth in the real economy. In order to achieve the objectives of the study, this paper will examine the effect of macroeconomic indicators (net foreign indirect investment, local deposits in Jordanian banks, domestic government debt, GDP and money supply (M2) on new issues in primary markets. This paper consider, the first of its kind in Jordan, according to the researcher.

\section{Literature Review}

According to (Faruqee, Li, \& Yan, 2004; Portes \& Rey, 2005; Duca, 2012) the capital inflow and outflow are very important now adays and the geographical component is very vital for the international flow of the capital. The capital inflow depends on the transaction cost and the market size of the host country.

According to the IMF survey the transaction cost, asymmetric information, and the market size are the vital determinants of the capital flow in the country. These major determinants are the driving factors of the portfolio investment. The crucial market events and the shocks change the portfolio investment driving factors. The foreign investors are very much concerned about the regional development after the overcome 
of the market tension. The extreme tension in the region made the investors panic and they started to move their funds out of the country or region.

According to the LO Duca 2012, the major factors affecting the capital inflows are GDP growth rate, market efficiency, and higher returns expectation. These factors play an important role in attracting the foreign investment. All these factors raise the macroeconomic level of the country by brought in the foreign investment which helps the country to rectify the deficit of the current account of the country. That leads the economy towards the growth. On the other side because of the volatility of this kind of investment, it can cause the economic crisis in the country. In the normal circumstances the foreign portfolio investment is very beneficial but when it flew out of the country it has the very disastrous effect on the economy.

Ibrahim T. R. and A kinbobol T.O(2017) examined the relationship between foreign portfolio investment, democracy and economic growth in Nigeria. This was with a view to explore the nexus between foreign indirect investment ( FII), democracy and economic growth in Nigeria. The results showed that FII inflow was more stable in democratic periods between 1999 and 2013 than the military periods between 1986 and 1998 and that the correlation between economic growth and FII is positive and very significant. The result showed that in the longrun foreign portfolio investment had positive and significant effect on the economic growth in Nigeria that democracy in itself affected economic growth significantly and positively but democratic government had no significant effect on the relationship between FII and economic growth.

Haider el (2017) investigating the impact of stock market performance and inflation on foreign indirect investment (FII) in China. For this purpose, time series quarterly data from 2007Q1 to 2015Q4 is used. The results show that there is significant positive impact of stock market performance on the FII, whereas inflation is found to be negatively associated with the FII. The study also reveals that some historical events like Asian financial crisis of 2008, and the Shanghai Composite Stock Index crash of 2015, significantly affected the FII in China. The investors should consider these two factors while investing in foreign financial markets.

Baghebo (2014), examine the impact of foreign Indirect investment(FII) on economic growthand long run determinant of FPI in Nigeria for the period 1986-2011. Augmented Dickey Fuller Unit Root Test, Johansen Co-integration test and Parsimonious Error Correction.

Result were adopted as method of analysis. The variables like foreign indirect investment, inflation rate, market capitalization, GDP and trade openness were considered for this study. It was discovered that FII, market capitalization and trade openness have a positive long-run relationship with Gross Domestic Product in Nigeria. It was recommended that authorities should strengthen the activities of capital market against fraudulent act and ensure friendly business policies as well as inflationary control in the economy. Chaudhry, Farooq and Mushtaq (2014) in their empirical study ascertained the factors affecting the portfolio investment in Pakistan over the period 1981-2012. Autoregressive model of partial adjustment with least-square method was employed to test the impact of market capitalization, weighted average rate of return on deposit, trade openness, money supply and foreign direct investment on the dependent variable (Net Portfolio Investment). The result revealed that FDI has negative impact on NPI while all other variables have positive impact on NPI. It was therefore recommended that government in Pakistan should protect its financial sector against terrorism.

Idowu (2015) investigated the major determinants of foreign Indirect investment inflows in Nigeria taking corruption, conflict law and order as well as socio economic condition into consideration. The result revealed that changes in real exchange rate, inflation rate, stock market capitalization had no effect on the inflows of FII under the period of study. It was also discovered that internal conflict and corruption have a negative significant effect on FII inflows. The study recommended that capital market should have freedom of operation and ensure practices of high ethics and professionalism to improve their operations. 
Fayyaz, Muhammed and Su-chang (2015) ascertained the determinants of foreign portfolio inflows, analysis and implication for China for the period 2001-2010. This was compared with the determinants of FII in India explored by Garg and Dua (2014). The result revealed that external debts are the most significant determinant of FII. It was therefore concurred with Garg and Dua (2014) that GDP, FDI and Exchange rate are the significant determinants of FII. It was recommended that China need to sustain its economic growth to attract more FII.

Aizenman, Jinjarak and Park (2011) examine the relationship between growths and lagged international capital flows, disaggregated into FDI, portfolio investment, equity investment and short term debt for the period of 1990-2010. Presenting results for the OLS regression of the growth rate of GDP per capital on the growth rate of FDI inflow, other controls, and interaction terms, the outcome was complex and mixed. The relationship between growth and lagged capital flows depends on the type of flows, economic structure, and global growth patterns. The study discovered that there is a large and robust relationship between FDI - both inflows and outflows and growth. The relationship between growth and equity flows is smaller and less stable. Finally, the relationship between growth and short-term debt is negative.

Benson (2003) examines the effects of foreign indirect investment (FII) and other foreign investment (OFI) on economic growth using data on 88 countries from 1977 to 2000. The results suggest that FII has no effect, and some results indicate that OFI has a negative impact on growth that is somewhat mitigated by initial financial and/or legal development. However, these results are questionable due to possible simultaneity bias. The empirical analyses also examine whether non-FDI foreign investment affects growth indirectly. FII does not correlate positively with macroeconomic volatility, but the results indicate that the negative indirect effect of OFI through macroeconomic volatility comprises a substantial portion of the gross negative effect of OFI on growth.

Okafor, Ugwuegbe and Chijindu (2016) investigated the relationship between foreign capital inflows and economic growth in Nigeria covers the period of 1981-2014. Foreign capital was peroxide by foreign direct investment, foreign portfolio investment and foreign while economic growth was peroxide by Gross Domestic Product and data was sourced from CBN statistical bulletin. Tada Yamamoto test of causality was adopted to analyze the relationship between foreign capital inflows and Nigeria economic growth. It was discovered that there is bi-directional causality running from GDP to FDI and FDI to GDP. Also, there is unidirectional causality between FPI and GDP with causation running from FPI to GDP. In addition, the result revealed a unidirectional causality between GDP and FA with causation testing from FA to GDP. The joint causation between all the components of foreign capital inflow show that the increase on foreign capital inflow will also leads to increase in GDP. The study therefore recommended that government should design some policies and programs to boost the now of foreign capital in order to enhance economic growth.

Ekeocha, Ekeocha, Malaolu and Oduh (2012) in their empirical study investigated the long run determinants of foreign portfolio investment in Nigeria for the period 1981-2010. Real exchange rate, Interest rate, market capitalization, trade openness and GDP were the variables considered in the study. The data were analyzed using Ventor Error Correlation Model (VECM) to test the long run determinants of foreign portfolio investment. The Comparative Jour | 167 Akanyo and Ajie (2015) examine the impact of capital flows on economic growth in Nigeria for the period of 1981-2012. Johansen co-integration test was adopted to analyze the data. The results revealed that a net increase in capital flows, especially of foreign direct investment by 1 percent would increase the level of economic growth by 33 percent in Nigeria while a percentage increase in foreign capital flows lead to 40 percent increase in economic growth. The study recommended that the authorities should maintain stable exchange rate regime to boost the preference of investors on domestic financial asset over foreign asset.

Orji, Uche and Ilori (2014) ascertained the implications of four different types of foreign capital inflows namely; Foreign Direct Investment (FDI), Official Development Assistance (ODA), Foreign Private 
Investment (FPI) and Remittances (REM) on output growth of West Africa Monetary Zone (WAMZ) economies for the period of 1981-2010.Ordinary Least Square Method (OLS) was adopted to analyze the data. The result shows that more than one form of capital inflow contributed positively to output growth in Nigeria. It was discovered that ODA has positive contribution to output growth in Sierra Leone and Ghana while FDI foster more output growth in Nigeria and Gambia. Remittances have the highest contribution in Liberia and finally none of the inflows has positively impacted on Guinea's economic growth. The study therefore recommendedthat West African Monetary Zone (WAMZ) countries should give rooms for competitive economic environment to attract foreign investors and ensure sound economic policies

According to (Egly, Johnk, \& Liston, 2010; Forbes, 2010; Gwenhamo \& Fedderke, 2013). The main determinant of the foreign portfolio investment in the United States of America is the financial development of the country.

The countries mostly invest in the United States because of less financial development. The countries internal factors affect the capital inflow and outflow of the country. The country institutional and domestic risks have a direct relation with the capital inflows and outflows. If the countries have good institutional setup and less domestic risk is more likely to have more foreign portfolio investment. Like, South Africa have more strong institutional setup have secure property rights and low domestic risk affects positively to the volume of capital flows in the South Africa both the FDI and FPI.

Specifically, international capital flows into foreign direct investment and foreign portfolio investment was broken down by the authors. The results they got show that there was the hostile effect of portfolio investment on growth but Foreign Direct Investment was absolutely associated with economic growth. FDI have a negative impact on growth in Pakistan economy.

As per (Parthapritam, 2006) in order to attract foreign portfolio investments there has also been competition among the emerging markets, through this it reached to a position at where it become important for the developing countries for portfolio investors they must have to ensure attractive returns for them, frequently it means that they offer an increase in the operational flexibility.

Loice Koskei (2017) investigated the effect of foreign portfolio equity outflows on stock returns of listed financial institutions in Kenya. The study population was 21 financial institutions listed on the Nairobi Securities Exchange. Using purposive sampling technique the study concentrated on 14 financial institutions. The research design of the study was causal as it is concerned more with understanding the connection between cause and effect relationships. The study adopted panel data regression using the Ordinary Least Squares (OLS) method where the data included time series and cross-sectional. Panel estimation results indicated that foreign portfolio equity outflows have no effect on stock returns of listed financial institutions in Kenya. The study recommended implementation of policies that would curb foreign portfolio outflows in financial institutions in order to minimize reversals of foreign portfolio investments.

Rasmane Ouedraogo (2017)exploring the impact of the inflows of portfolio capital into three institutional sectors (government, banks and corporates) on the real effective exchange rate. Using a large sample of 73 countries, it shows that the effect of portfolio inflows on the real effective exchange rate depends on the sector the investment flows in. The results are robust to different econometric methods, additional variables in the model, and various indicators of real effective exchange rates.

Sameh Abu Sanab (2017) investigated the effect of foreign portfolio investment (FPI), both in buying of shares or sale of shares by foreign investors, inflation and gross domestic product on the market capitalization in the Amman Stock Exchange for the period 2005-2016. The study concluded that there is a statistically significant effect on both the purchases and sales by foreign investors on market capitalization. The study also found no statistically significant effect between inflation and market capitalization 


\section{Contribution of this Paper}

This paper contributes to finding the impact of the foreign indirect investment on new issues in primary financial market in the case of Jordan. Jordan needs special focus because foreign portfolio investment has significantly increased in the country since the late 2004s.

\section{Methodology}

The data of NFII, ND, IGD,GDP,MS(M2) and NI have been taken from the ASE \& Central Bank of Jordan publications. Sixteen observations have been collected and put under analysis, from 2005 to 2016. The data has been taken on the annual bases and the currency unit used is JD (Jordanian Dinar).

$\mathrm{NI}=\mathrm{f}$ (NFII, ND, IGD,GDP,M2), where NI is dependent variable and NFII, ND, IGD,GDP,MS are independent variables .

The methodology employed for this study was based on the following model.

$\mathrm{Y}=\mathrm{f}(\mathrm{X} 1, \mathrm{X} 2, \mathrm{X} 3, \mathrm{X} 4, \mathrm{X} 5$, $)$ where $\mathrm{Y}$ is dependent variable and $\mathrm{X} 1, \mathrm{X} 2, \mathrm{X} 3, \mathrm{X} 4$ and $\mathrm{X} 5$ are independent variables .

$\mathrm{Y}=\mathrm{a}+\mathrm{b}_{1} \mathrm{X} 1+\mathrm{b}_{2} \mathrm{X} 2+\mathrm{b}_{3} \mathrm{X} 3+\mathrm{b}_{4} \mathrm{X} 4+\mathrm{b}_{5} \mathrm{X} 5+\mathrm{U}_{\mathrm{t}}$

Where :

$\mathrm{Y}=\mathrm{New}$ Issues in the primary Market

$\mathrm{X} 1=$ Net Foreign indirect investment.

$\mathrm{X} 2=$ National deposits in Jordan banks

$\mathrm{X} 3=$ Internal Government debt

X4= Gross Domestic product.

X5: Money supply (M2)

$\mathrm{a}, \mathrm{b}_{1}, \mathrm{~b}_{2}, \mathrm{~b}_{3}, \mathrm{~b}_{4}, \mathrm{~b}_{5}$, is constant

$\mathrm{U}=$ random error.

\section{Hypotheses}

The following Hypothesis has been developed on the basis of previous literature.

$\mathrm{H}_{01}$ : There is no statistically significant relationship between net foreign indirect investment and the new issues of listed companies on the ASE

$\mathrm{H}_{02}$ : There is no statistically significant relationship between the national deposits and the new issues of listed companies on the ASE

$\mathrm{H}_{03}$ : On Securities, there is no statistically significant relationship between government domestic debt and the new issues of listed companies on the ASE

$\mathrm{H}_{04}$ : On Securities, there is no statistically significant relationship between GDP and the NEW ISSUES of listed companies on the ASE.

$\mathrm{H}_{05}$ : On Securities, there is no statistically significant relationship between Money supply(M2) and the NEW ISSUES of listed companies on the ASE. 


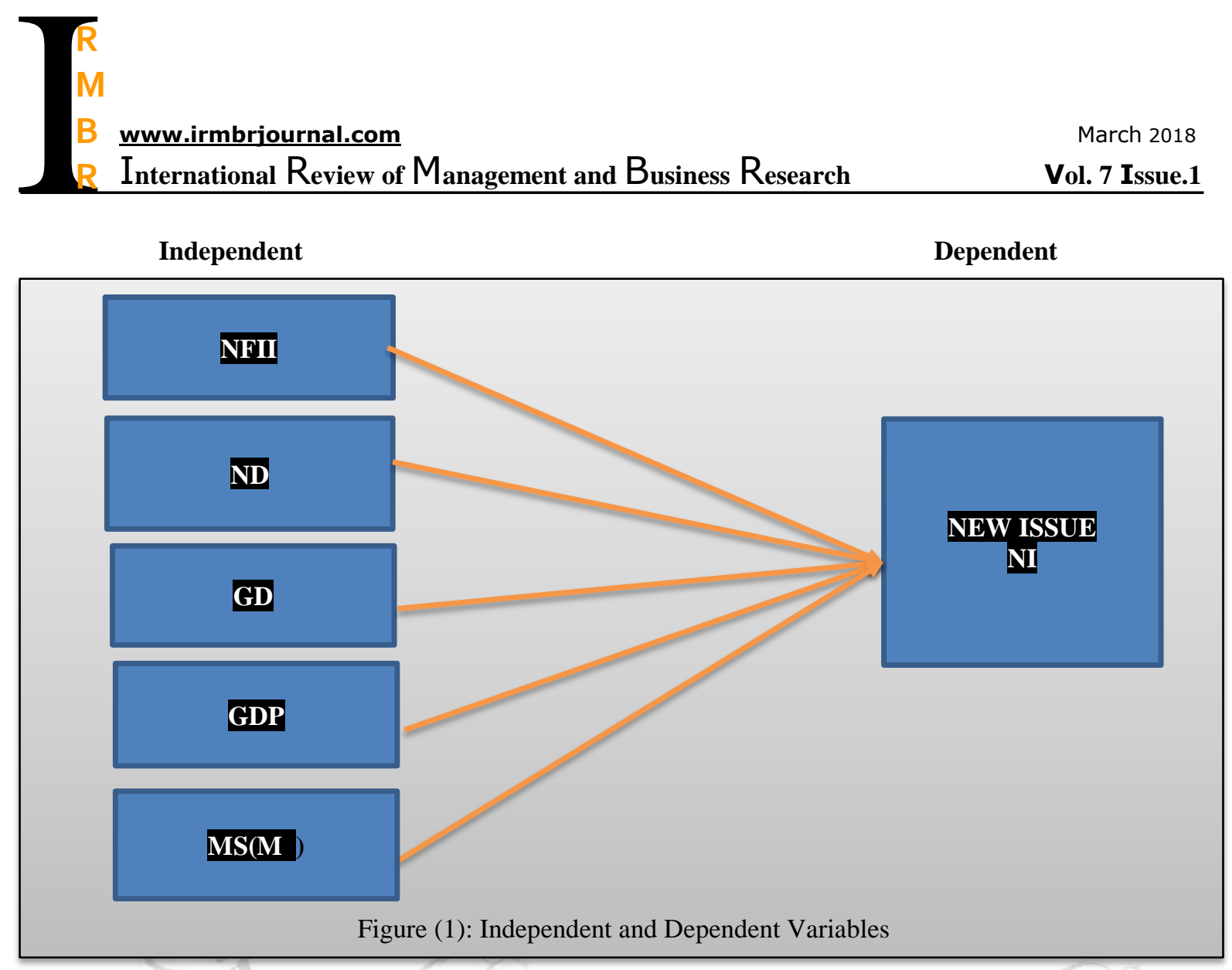

\section{Findings and Discussions}

Table (1) summarizes this research's main data, on which further analysis and discussion proceed.

Table (1). NI, NFII, ND,GDP and M2 ( 2005-2016)

\begin{tabular}{|c|c|c|c|c|c|c|}
\hline & & & & & Million \\
\hline Year & NI & NFII & ND & IG D & IGP & M2 \\
\hline 2005 & 888.83 & 2152.2 & 8364.4 & 1808.3 & 8953.2 & 12364 \\
\hline 2006 & $2,408.84$ & 1995.1 & 9427.1 & 1467.7 & 10521 & 141117 \\
\hline 2007 & 885.77 & 2825.3 & 10618 & 2099.9 & 11721 & 156078 \\
\hline 2008 & 827.96 & 4219.8 & 13348.5 & 4120.5 & 14189 & 18304 \\
\hline 2009 & 317.32 & 2135.5 & 15865.1 & 4618.7 & 16912 & 20013 \\
\hline 2010 & 119.28 & 1036.6 & 17617.2 & 4907.2 & 18762 & 22307 \\
\hline 2011 & 136.67 & 555.8 & 19119.1 & 6701.4 & 20476 & 24119 \\
\hline 2012 & 144.83 & 233.9 & 17711.1 & 9461.3 & 21965 & 24945 \\
\hline 2013 & 45.98 & 939.5 & 21003 & 10494.8 & 23852 & 27363 \\
\hline 2014 & 65.82 & 362.7 & 24013.1 & 10473.9 & 25437 & 29240 \\
\hline 2015 & 40.55 & 981.7 & 26014.5 & 11386.4 & 26637 & 31605 \\
\hline 2016 & 178.24 & 666.5 & 25968.2 & 10453.8 & 27445 & 32876 \\
\hline
\end{tabular}


Charts 1, 2, 3 and 4 represent respectively: NFII, ND, IGD, GDP\& M2 with NI.

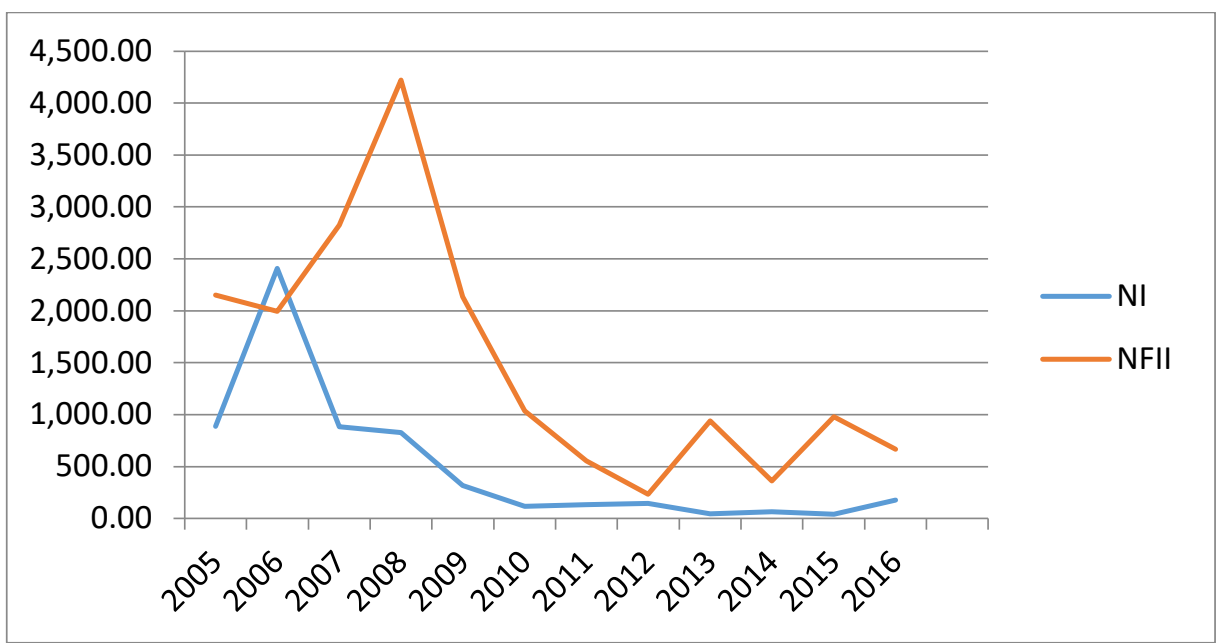

Figure 2. NFII and NI 2005-2016

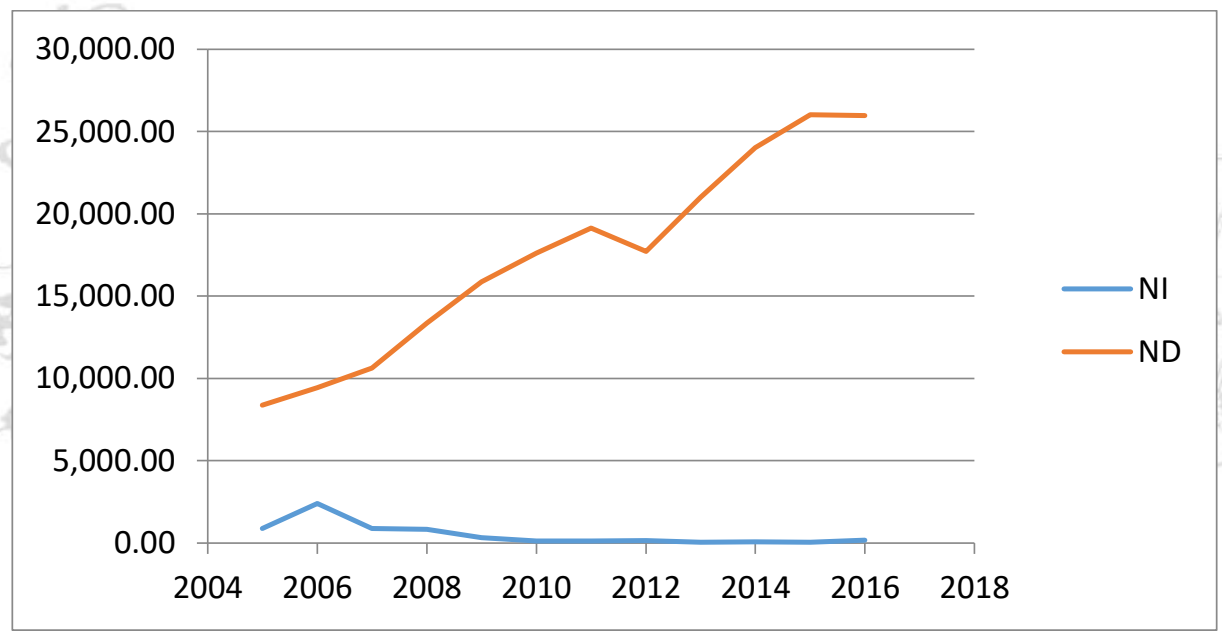

Figure 3. ND and NI 2005-2016

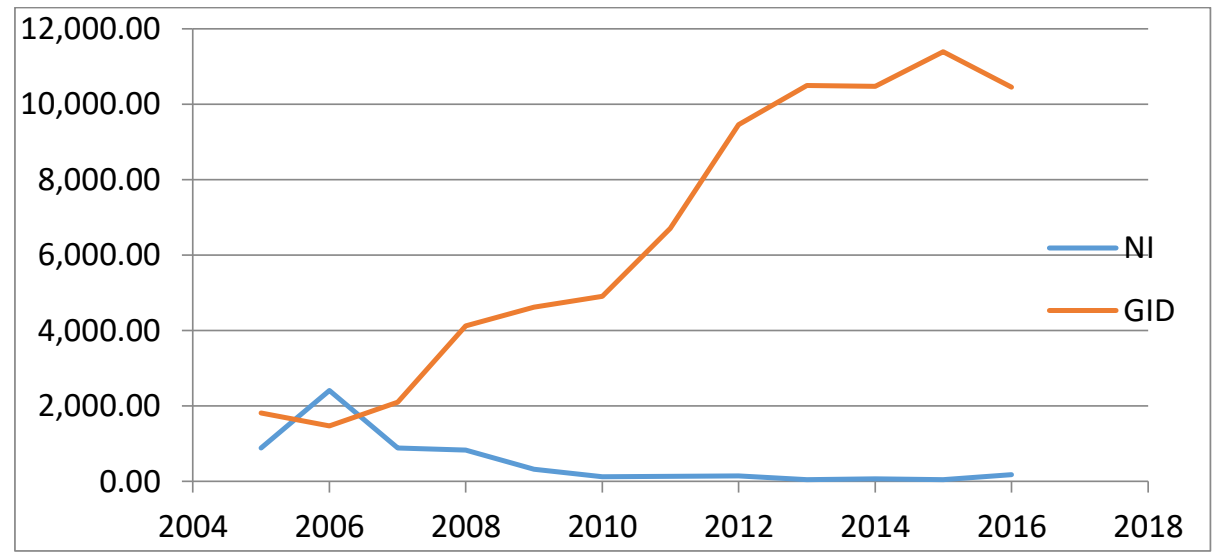

Figure 4. IGD and NI 2005-2016 


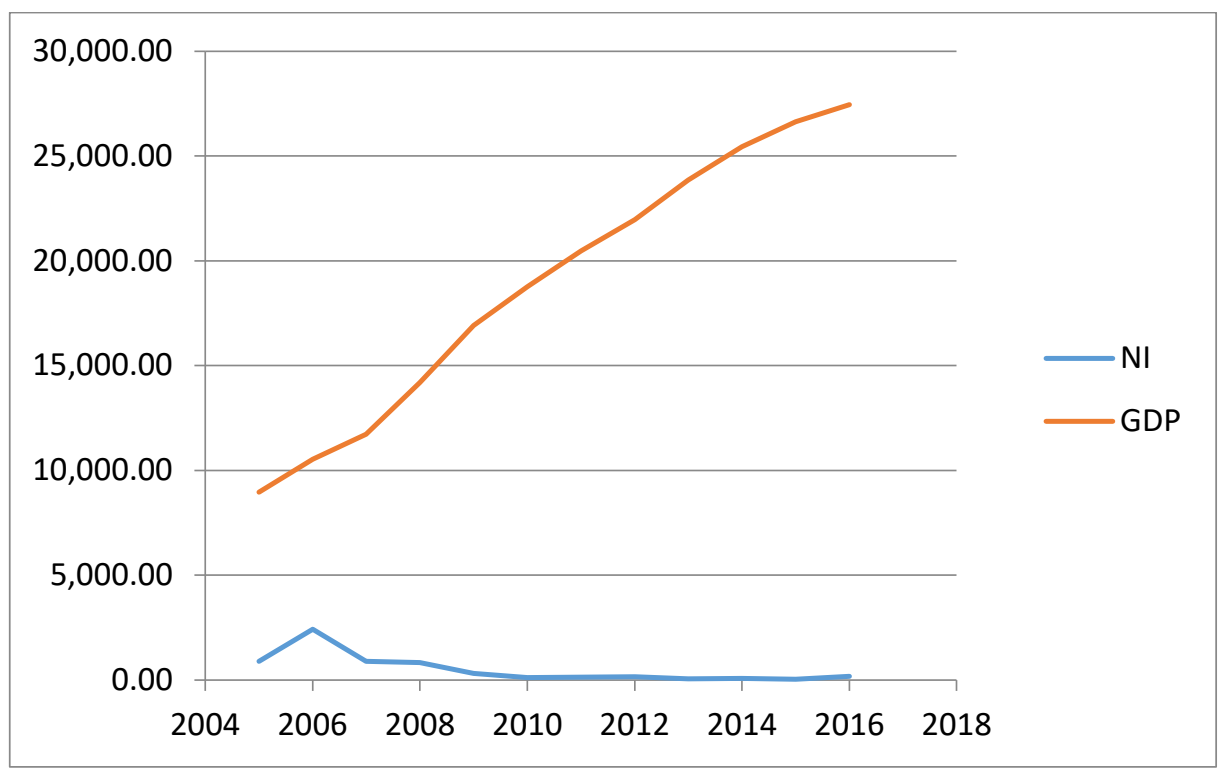

Figure 5. GDP and NI 2005-2016

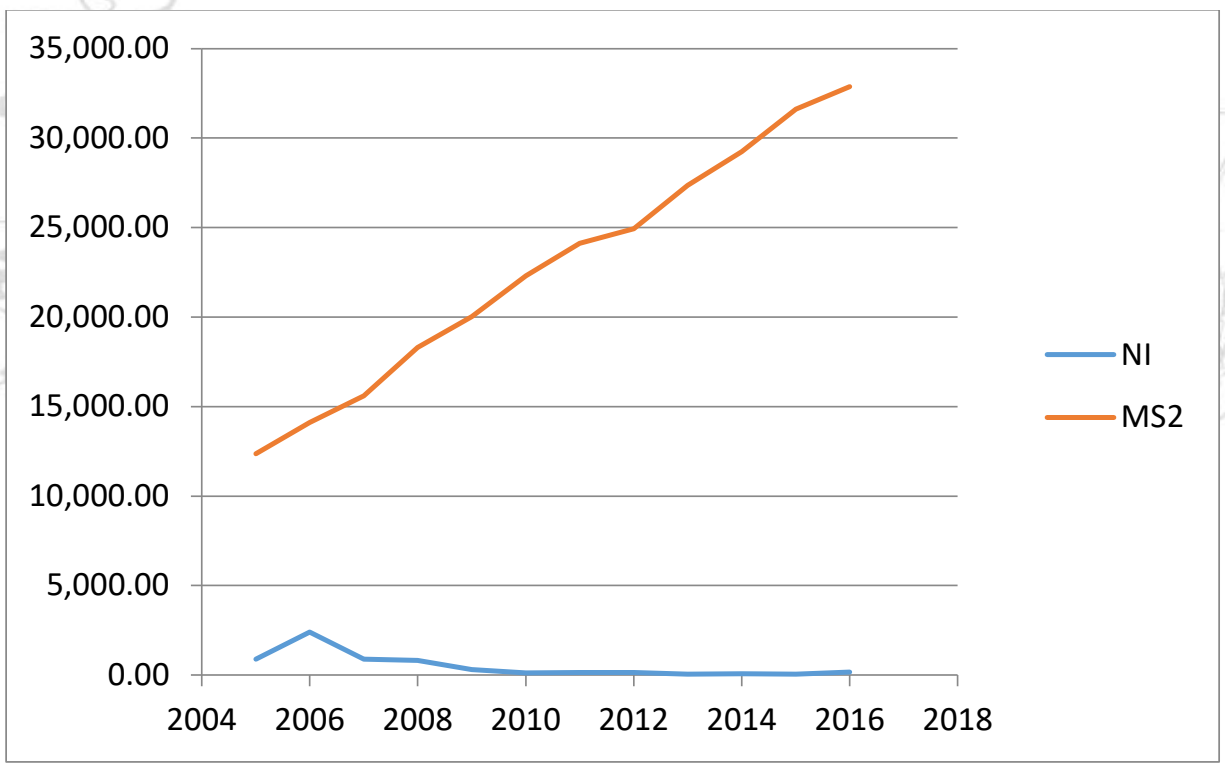

Figure 6. M2 and NI 2005-2016

In order to test the hypotheses of the research, the collected data that relates to the independent variables of the research and the dependent variable were analyzed, utilizing the statistical analysis package SPSS. In the first stage, the overall combined effect of the independent variables was measured, i.e., the net foreign indirect investment, National deposits in Jordanian banks, Government general debt, Gross Domestic product, Money supply (M2) on the new issues of the companies listed on the Amman Stock Exchange during the period covered by the research (2005-2016). This analysis is necessary to know the overall effect of all the independent variables on the dependent variable. Multiple Regression served for achieving this stage. The second stage consisted of testing the four hypotheses of the research using simple regression analysis. The results of the analysis are as follows: 
A. The impact of the Net foreign indirect investment, National deposits in Jordan banks, Government general debt Gross Domestic product, Money supply (M2) on the new issues of the companies listed on the Amman Stock Exchange:

Table (2) Coefficients ${ }^{\mathrm{a}}$

\begin{tabular}{|c|c|c|c|c|c|c|}
\hline \multirow{2}{*}{\multicolumn{2}{|c|}{ Model }} & \multicolumn{2}{|c|}{ Unstandardized Coefficients } & $\begin{array}{c}\text { Standardized } \\
\text { Coefficients }\end{array}$ & \multirow[b]{2}{*}{$\mathrm{T}$} & \multirow[b]{2}{*}{ Sig. } \\
\hline & & $\mathrm{B}$ & Std. Error & Beta & & \\
\hline \multirow[t]{6}{*}{1} & (Constant) & 1174.579 & 1696.157 & & .692 & .515 \\
\hline & $\mathrm{X} 1$ & $-.150-$ & .228 & $-.258-$ & $-.655-$ & .537 \\
\hline & $\mathrm{X} 2$ & $-.140-$ & .242 & $-1.257-$ & $-.579-$ & .584 \\
\hline & $\mathrm{X} 3$ & .003 & .212 & .016 & .014 & .989 \\
\hline & $\mathrm{X} 4$ & $-.489-$ & .391 & $-4.592-$ & $-1.251-$ & .258 \\
\hline & X5 & .493 & .358 & 4.898 & 1.379 & .217 \\
\hline
\end{tabular}

a. Dependent Variable: Y

Table (2) shows that there is no statistically significant effect for all independent variables, taken together, on the dependent variable at $10 \%$ significance level. The table shows that the values of the statistical significance of the independent variables: the net foreign indirect investment, National deposits in Jordan banks, Government general debt Gross Domestic product, Money supply (M2) were (0.537, 0.584, $0.989,0.258$ and 0.217$)$ respectively, and each was higher than $(0.10)$.

Table (3) Model Summary

\begin{tabular}{|c|c|c|c|c|}
\hline Model & $\mathrm{R}$ & $\mathrm{R}$ Square & Adjusted R Square & $\begin{array}{c}\text { Std. Error of the } \\
\text { Estimate }\end{array}$ \\
\hline 1 & $.821^{\mathrm{a}}$ & .674 & .403 & 531.07202 \\
\hline
\end{tabular}

a. Predictors: (Constant), X5, X1, X3, X2, X4

Table (3) shows The value of the coefficient of determination $\left(\mathrm{R}^{2}\right)$ indicates that independent variables, taken as a whole, explain about (0.674) of the volume of changes that occur in the dependent variable.

Table (4) Coefficients ${ }^{\mathrm{a}}$

\begin{tabular}{|c|c|c|c|c|c|c|}
\hline \multirow{2}{*}{\multicolumn{2}{|c|}{ Model }} & \multicolumn{2}{|c|}{ Unstandardized Coefficients } & $\begin{array}{l}\text { Standardized } \\
\text { Coefficients }\end{array}$ & \multirow[b]{2}{*}{$t$} & \multirow[b]{2}{*}{ Sig. } \\
\hline & & $\mathrm{B}$ & Std. Error & Beta & & \\
\hline 1 & $\begin{array}{c}\text { (Constant) } \\
\text { X1 }\end{array}$ & $\begin{array}{c}46.864 \\
.304\end{array}$ & $\begin{array}{c}294.412 \\
.156\end{array}$ & .525 & $\begin{array}{l}.159 \\
1.948\end{array}$ & $\begin{array}{l}.877 \\
.080\end{array}$ \\
\hline
\end{tabular}

a. Dependent Variable: Y

B. first hypothesis test: Table (4) indicates the existence of a statistically significant effect of the independent variable (Net foreign indirect investment NFII) on the new issue of shares; as its statistical significance value was $(0.080)$, which is less than 0.10 .

Table (5) Model Summary

\begin{tabular}{|c|c|c|c|c|}
\hline Model & $\mathrm{R}$ & $\mathrm{R}$ Square & $\begin{array}{c}\text { Adjusted R } \\
\text { Square }\end{array}$ & $\begin{array}{c}\text { Std. Error of the } \\
\text { Estimate }\end{array}$ \\
\hline 1 & $.525^{\mathrm{a}}$ & .275 & .203 & 613.73525 \\
\hline
\end{tabular}

a. Predictors: (Constant), X1 
Table (5) indicates that The value of the coefficient of determination indicates that this variable explains $(0.275)$ of the volume of changes occurring in the dependent variable.

Table (6) Coefficients ${ }^{\mathrm{a}}$

\begin{tabular}{|c|c|c|c|c|c|c|}
\hline \multirow{2}{*}{\multicolumn{2}{|c|}{ Model }} & \multicolumn{2}{|c|}{ Unstandardized Coefficients } & \multirow{2}{*}{$\frac{\text { Standardized Coefficients }}{\text { Beta }}$} & \multirow[b]{2}{*}{$t$} & \multirow[b]{2}{*}{ Sig. } \\
\hline & & $\mathrm{B}$ & Std. Error & & & \\
\hline 1 & $\begin{array}{c}\text { (Constant) } \\
\text { X2 }\end{array}$ & $\begin{array}{l}1942.440 \\
-.083-\end{array}$ & $\begin{array}{c}436.936 \\
.024\end{array}$ & $-.739-$ & $\begin{array}{r}4.446 \\
-3.473-\end{array}$ & $\begin{array}{l}.001 \\
.006\end{array}$ \\
\hline
\end{tabular}

a. Dependent Variable: Y

C. Second hypothesis test: table (6) indicates the existence of a statistically significant effect of the independent variable (National deposits in Jordanian banks NDJB) on the new issues of shares; as its statistical significance was (0.06), which is less than( 0.10$)$.

Table (7) Model Summary

\begin{tabular}{|c|c|c|c|c|}
\hline Model & $\mathrm{R}$ & R Square & Adjusted R Square & Std. Error of the Estimate \\
\hline 1 & $.739^{\mathrm{a}}$ & .547 & .501 & 485.32283 \\
\hline
\end{tabular}

a. Predictors: (Constant), X2

The coefficient of determination value indicates that this variable explains (0.547) of the volume of changes in the dependent variable.

Table (8) Coefficients ${ }^{\mathrm{a}}$

\begin{tabular}{|cc|c|c|c|c|c|}
\hline \multirow{2}{*}{ Model } & \multicolumn{2}{|c|}{ Unstandardized Coefficients } & \multicolumn{2}{|c|}{ Standardized Coefficients } & \multicolumn{1}{|c|}{} & \multirow{2}{*}{ Sig. } \\
\cline { 3 - 7 } & & $\mathrm{B}$ & Std. Error & Beta & 4.757 & .001 \\
& (Constant) & 1371.816 & 288.399 & & $-3.444-$ & .006 \\
\hline
\end{tabular}

a. Dependent Variable: Y

D. Third hypothesis test: Table (8) shows that there is a statistically significant effect of the independent variable (Government general debt) on the market value of shares; as the value of statistical significance was (0.060), which is higher than (0.10).

Table (9) Model Summary

\begin{tabular}{|c|c|c|c|c|}
\hline Model & R & R Square & Adjusted R Square & Std. Error of the Estimate \\
\hline 1 & $.737^{\mathrm{a}}$ & .543 & .497 & 487.59109 \\
\hline
\end{tabular}

a. Predictors: (Constant), X3

The value of the coefficient of determination indicates that this variable explains $(0.543)$ of the volume of changes in the dependent variable.

Table (10) Coefficients ${ }^{\mathrm{a}}$

\begin{tabular}{|cc|c|c|c|c|c|}
\hline \multirow{2}{*}{ Model } & \multicolumn{2}{|c|}{ Unstandardized Coefficients } & Standardized Coefficients & \multirow{2}{*}{$\mathrm{t}$} & \multirow{2}{*}{ Sig. } \\
\cline { 3 - 7 } & & $\mathrm{B}$ & Std. Error & Beta & 4.757 & .001 \\
\cline { 3 - 7 } 1 & (Constant) & 1371.816 & 288.399 & & $-3.444-$ & .006 \\
\hline
\end{tabular}

a. Dependent Variable: Y 
E. Fourth hypothesis test: Table (10) indicates that there is a statistically significant effect of the independent variable (GDP) on the new issues of shares, as its statistical significance value is 0.060 , which is less than 0.10 .

Table (11) Model Summary

\begin{tabular}{|c|c|c|c|c|}
\hline Model & $\mathrm{R}$ & R Square & $\begin{array}{c}\text { Adjusted R } \\
\text { Square }\end{array}$ & $\begin{array}{c}\text { Std. Error of the } \\
\text { Estimate }\end{array}$ \\
\hline 1 & $.737^{\mathrm{a}}$ & .543 & .497 & 487.59109 \\
\hline
\end{tabular}

b. Predictors: (Constant), X3

The value of the coefficient of determination indicates that this variable explains $(0.543)$ of the volume of changes in the dependent variable.

Table (12) Coefficients ${ }^{\mathrm{a}}$

\begin{tabular}{|c|c|c|c|c|c|}
\hline \multirow[t]{2}{*}{ Model } & \multicolumn{2}{|c|}{ Unstandardized Coefficients } & \multirow{2}{*}{$\begin{array}{c}\begin{array}{c}\text { Standardized } \\
\text { Coefficients }\end{array} \\
\text { Beta }\end{array}$} & \multirow[b]{2}{*}{$\mathrm{t}$} & \multirow[b]{2}{*}{ Sig. } \\
\hline & $\mathrm{B}$ & Std. Error & & & \\
\hline $\begin{array}{c}\text { (Constant) } \\
\text { X5 }\end{array}$ & $\begin{array}{c}2174.271 \\
-.073-\end{array}$ & $\begin{array}{c}516.096 \\
.022\end{array}$ & $-.729-$ & $\begin{array}{r}4.213 \\
-3.365-\end{array}$ & $\begin{array}{l}.002 \\
.007\end{array}$ \\
\hline
\end{tabular}

F. Fifth hypothesis test: Table (12) indicates that there is a statistically significant effect of the independent variable (Money Supply (M2)) on the new issues of shares, as its statistical significance value is 0.070 , which is less than 0.10 .

Table(13) Model Summary

\begin{tabular}{|c|c|c|c|c|}
\hline Model & R & R Square & Adjusted R Square & Std. Error of the Estimate \\
\hline 1 & $.729^{\mathrm{a}}$ & .531 & .484 & 493.65161 \\
\hline
\end{tabular}

a. Predictors: (Constant), X5

The value of the coefficient of determination indicates that this variable explains $(0.531)$ of the volume of changes in the dependent variable.

\section{Conclusion}

In this paper investigated, In the first stage, the overall combined effect of the independent variables was measured, i.e., the net foreign indirect investment, National deposits in Jordanian banks, Government internal debt, Gross Domestic product, Money supply (M2) on the new issues of the companies listed on the Amman Stock Exchange during the period covered by the research (2005-2016). This analysis is necessary to know the overall effect of all the independent variables on the dependent variable. Multiple Regression served for achieving this stage. The second stage consisted of testing the four hypotheses of the research using simple regression analysis. The study covered the period in which oil prices rose sharply, creating cash surpluses in the oil-exporting countries. Some of these surpluses were directed to investment in securities, which increased the demand for securities. The target was speculation and quick profit. The total foreign demand for securities reached a peak in 2008, with foreign investment in securities on the Amman Stock Exchange reaching (4220) million dinars. This coincided with an unprecedented rise in the price of a barrel of oil, which, in the middle of the same year (2008), reached $\$ 149$ a barrel, followed by a sharp decline in oil prices in the second half of 2008 and subsequent years. The decline was accompanied by the foreigners' sale of their investment in Amman Financial Market, which resulted in a sharp volatility in the prices of securities. This confirms the positive relationship between oil prices and the volume of foreign investments in the Amman stock exchange. 
The researcher utilized statistical analysis tools to study the effect of independent variables (FII, ND, IGD, GDP,M2) on the dependent variable (NI). The study found a statistically significant relationship between independent variables with NI.

\section{References}

Ahmad, F., Draz, M. U., \& Yang, S. C. (2015). Determinants of Foreign Portfolio Inflows: Analysis and Implications for China. Asian Journal of Finance \& Accounting, 7(2), 66-77. http://dx.doi.org/10.2139/ssrn.25426

Aizenman, I., Jinjarak, Y. \& Park, D. (2011). Capital ows and economic growth in the era of $\square$ nancial integration and crisis, 1990-2010. NBER working paper. pp.1-2

Akanyo, B. A. \& Ajie, .H.A (2015). Impact of capital ows on the Nigerian economy in a globalize environment, (1981-2012).International Journal of Business and Finance Management Research. ISSN 2053-1842, 3.pp.6-1810.

Anuradha Sheokand:: A comprehensive study on Under Pricing in Indian Initial Public Offerings gInternational Journal of Informative \& Futuristic Research (IJIFR) Volume - 2, Issue - 8, April 2015 20th Edition, Page No: 2507-2517.

Aurangzeb,\& A. Ul Haq. (2012). Impact of Foreign Capital Inflows on Economic Growth in Pakistan. European Journal of Economics, Finance and Administrative Sciences, 46.

Baghebo, M. (2014). Foreign portfolio investment and economic growth in Nigeria, International Journal of Business and Social Science.5, (11), .pp.108-115.

Chaudhry I. S., Farooq, F., \& Mushtaq, A. (2014). Factor affecting portfolio investment in Pakistan: Evidence from time series analysis, Pakistan economic and Social Review, 52(2), pp 141-158.

Durham, J. Benson, Foreign Portfolio Investment, Foreign Bank Lending, and Economic Growth (February 2003). FRB International Finance Discussion Paper No. 757. Available:at: https://ssrn.com/abstract=382063 or http://dx.doi.org/10.2139/ssrn.382063.

Egly, P. V., Johnk, D. W., \& Liston, D. P. (2010). Foreign Portfolio Investment Inflows to the United States: The Impact of Risk Aversion and US Stock Market Performance. North American Journal of Finance and Banking Research, 4(4), 25-41.

Ekeocha, P. C., Ekeocha, C.S., Malaolu, V. \& Oduh, M. O. (2012). Modeling the long run determinants of foreign portfolio investment in Nigeria, Journal of Economic and Sustainable Development, ISSN 2222-1700, 3, (.8). pp. 194-205.

Fayyaz, A., Muhammed, U. D., \& Su-chang, Y. (2015). Determinants of foreign portfolio In ows: Analysis and implications for China, Asian Journal of Finance and Accounting I (2) .pp.66-77.

Faruqee, H., Li, S., \& Yan, I. K. (2004). The Determinants of International Portfolio Holdings and Home $\operatorname{Bias}($ Vol. 4).Washington, DC: International Monetary Fund.

Forbes, K. J. (2010). Why do foreigners invest in the United States? Journal of International Economics, 80(1), 3-21. http://dx.doi.org/10.1016/j.jinteco.2009.09.001

Gwenhamo, F., \& Fedderke, J. W. (2013). The composition of foreign capital stocks in South Africa: The role of institutions, domestic risk and neighbourhood effects. Economic Modelling, 35, 763-770. http://dx.doi.org/10.1016/j.econmod.2013.09.001

Ibrahim T. R. And Akinbobola T. O.(2017) . "Foreign Portfolio Investment and Economic Growth in Nigeria Democratic Settings",

Idowu, O. O. (2015). Foreign portfolio investment in Nigeria, International Journal of Social Relevance and Concern 3 (5), .pp.3-19.

Khakan Najaf, Rabia Najaf (2016), Impact of foreign portfolio investment on the development of Pakistan, journal Business Management and economic 4: 06 june (2016), website : www.journalresearchijf.com

LoDuca,M.(2012).Modelling the time varying determinants of portfolio flows to emerging markets(August23,2012).

Loice Koskei, (2017), "The Effect of Foreign Portfolio Equity Sales on Stock Returns in Kenya: Evidence from NSE Listed Financial Institutions" 
Manas Mayur, Manoj Kumar (2006),An empirical investigation of going public decision of Indian companies, Working Paper Series (WPS), Indian Institute of Management, Lucknow WPS Number: 2006-07/06.

Muhammad Afaq Haider, Muhammad Asif Khan, Shamila Saddique, Shujahat Haider Hashmi ( 2017) "he Impact of Stock Market Performance on Foreign Portfolio Investment in China", International Journal of Economics and Financial Issues, 2017, 7(2), 460-468. available at http: www.econjournals.com

Muhammad Afaq Haider, Muhammad Asif Khan \& Elyas Abdulahi (2016),DeterminantsofForeignPortfolioInvestmentandItsEffectsonChina" International Journal of Economics and Finance; Vol. 8, No. 12; 2016

Okafor, I. G., Ugochukwu, U. S. \& Chijindu, E. H. (2016). Foreign capital in ows and Nigerian economic growth Nexus: A Toda Yamamoto approach, European Journal of Accounting, Auditing and Finance Research, 4, (3), pp.16-26.

Onyeisi,Ogbonna samuuel, Odo,Identyi Stephen and Anoke, Charity Ifeyinwa (2016), Foreign portofolio investment and stock market growth in Nigeria, Developing country studies, vol.6no.11,2016.

Orji, A., Uche, A. S., \& Ilori, E. A. (2014). Foreign capital in ows and growth: An empirical analysis of West Africa Monetary Zone. (W.A.M.Z.) experience, International Journal of Economics and Financial 4 (4), pp.971-983.

Petar S. rose (2003), money and capital markets, MC Grow. Hill PP14-15.

Rasmane Ouedraogo (2017), "Portfolio Inflows and Real Effective Exchange Rates", Journal of Economics and Sustainable Development,Vol.8, No.5.

Parthapratim (2006) Draft Paper Submitted for the Annual Conference on Development and Change Mission: Promoting Development in a Globalized World, Sao Paulo, Brazil, November 18 - 20, 2006

Sameh Abu shanab (2017) The Effect of Foreign Portfolio Investment (FPI) on Capital Market Indices, Jordan, International Review of Management and Business Research, volume 6, issue 4.

UNCTAD (1999). Foreign direct investment in Africa: Performance and potential. United Nations Publications. Unctad/ITE/IIT/Misc.15. New-York and Geneva. United Nations

Weston, el (1996), Essential of managerial finance, Dryden press, $11^{\text {th }}$ edition, New York. 